\title{
Current issues in LPP research and their impact on society
}

\author{
Jeroen Darquennes
}

\begin{abstract}
After a very broad description of what language policy and planning is about this paper presents an overview of some of the current preoccupations of researchers focusing on language policy and planning as one of the blooming fields of applied linguistics. The current issues in language policy and planning research that are dealt with include 'the history of the field', 'language practices in different domains of society', 'ideas and beliefs about language', and 'the practical side of language policy and planning. The brief sketch of current issues in language policy and planning research is meant to serve as the background for a preliminary discussion of the impact of language policy and planning research on society. That discussion takes the different 'roles' of academics working at university departments and doing research on language policy and planning as a starting point.
\end{abstract}

\section{Introduction}

Even though language policy and planning as human activities have been going on for centuries, systematic research on language policy and planning mainly took off in the 1960s when scholars from various backgrounds developed an interest in the study of 'societal language problems'. While giving shape to a multitude of crystalizing branches of 'hyphenated linguistics' in a timeframe characterised by ethnic revival in several parts of the world, many researchers focusing on differing aspects of language policy and planning subscribed to Fishman, Ferguson and Das Gupta's call to tackle the language problems in which the inhabitants of developing nations were "entrapped" (cf. Fishman, Ferguson \& Das Gupta 1968:x). As will be shown below, this early scholarly commitment has been and still is being scrutinized in a field of research that has considerably expanded since the 1960 s, i.e. both content-wise as well as in terms of the amount of attention it arouses from various disciplinary angles.

The fact that language policy and planning is approached from a variety of disciplinary perspectives (sociolinguistics, anthropology, economy, political science, political philosophy, legal studies, translation studies, ...) makes its already intrinsic multidimensional nature even more complex and renders it impossible to provide an all-encompassing overview of topical issues in language policy and planning research (cf. Schiffman 2013:3085). The overview of current research issues in language policy and planning as presented in Section 3 of this contribution is, therefore, perforce an inexhaustive and - given the limited space - also a parsimonious one. The brief sketch of some of the preoccupations of researchers focusing on language policy and planning as a blooming field of applied linguistics is mainly meant to provide the background for a preliminary discussion of a 
question that is central to this volume of the AILA Review, i.e. the question concerning the impact of language policy and planning research on society. That question is dealt with in Section 4 . To start with, however, this contribution in very broad terms describes what language policy and language planning are about and why use is made of what Hornberger (2006:25) refers to as the "LPP designation" (LPP = language policy and planning).

\section{What language policy and planning is about}

In very broad terms and inspired by ideas expressed in the works of, for example, Kaplan and Baldauf (1997:xi), Ricento (2000: 23 and 2010:212) and Schiffman (2013:3087) language policy can be understood as the whole body of oral and/or written (in)formal texts that aim at (re)affirming or changing the language dynamics in (a part or different parts of) society. Language planning can be considered as an attempt to influence the language dynamics in (a part or different parts of) society by means of concrete measures that address the corpus (cf. Haugen 1959, 1987 and Kloss 1969), the status (cf. the works of Haugen and Kloss as cited before), the acquisition (cf. Cooper 1989) and/or the prestige (cf. Haarmann 1990) of a single or more language varieties.

As to the interplay between language policy and language planning, some scholars hold the view that language planning precedes language policy (cf. Studer et al. 2008). Others hold the view that planning can precede policy, yet is in most cases preceded by it (cf. Fishman 1972) which does not, however, prevent planning measures from influencing already existing language policies in the short or in the long run. The fact that there is no absolute agreement on the exact nature of the inextricable relationship between language policy and language planning (cf. Schiffman 2013:3086) as well as the fact that much of the literature on language policy addresses language planning issues (and vice versa) is what makes the 'LPP designation' a useful one (cf. Hornberger 2006:25). On top of that, the LPP designation allows to extend the scope of the traditional interrelated language planning branches to language policy and to claim that LPP covers four dimensions or, inspired by Baldauf (2004:1) and Lo Bianco (2013:3096 and 3099), four kinds of interrelated 'activities' or 'actions':

1. Actions that aim at modifying the corpus of a language (variety) through the standardization and/or elaboration of its lexicon, grammar and/or orthography.

2. Actions that aim at influencing the social status and/or the functional range of a given language (variety) without necessarily having the intention to increase the number of people actually using it.

3. Actions that aim at raising the social prestige (or, in other words: the "reputation", cf. Lo Bianco 2013:3100) of a language (variety).

4. Actions that aim at promoting the acquisition of a language (variety) and, by doing so, at increasing its number of users.

Today, the actions presented above ${ }^{1}$ are considered to be part of a more traditional approach to language policy and planning that builds on and further refines the works of LPP pioneers such as Haugen, Kloss, Ferguson and Fishman. They still feature quite prominently in literature on indigenous language minorities as well as in many of the works on language standardization, language and nationalism, language and colonialism and linguistic imperialism. They do, however, also shine

1. As Baldauf (2004:2) states, the list of activity types makes sense "for descriptive-pedagogical purposes". One should, however, be aware of the fact that in reality the overlap and the interplay between these activities are far more complex than the neat division suggests. 
through in much of the literature that approaches language policy and planning questions through primarily focusing on issues such as the ones listed in the next section.

\section{Current issues}

When browsing literature on language policy and planning within the related and partially overlapping disciplines of sociolinguistics, the sociology of language and contact linguistics (cf. Wildgen 2005 on the overlap), one comes across a number of possible ways to subdivide the LPP field. Subdivisions are made, for example, on the basis of a distinction between macro, meso and micro LPP activities, between LPP goals, processes and actual outcomes, between top-down and bottomup LPP activities, between overt and covert LPP, or between various domains in which LPP takes place (cf. Kaplan \& Baldauf 1997; Spolsky 2004; Spolsky 2009). Rather than reduplicating these possible subdivisions, this contribution follows the footsteps of Ricento (2006), who devotes the third section of his edited volume on language policy to topical issues. Whereas Ricento's volume distinguishes rather specific topical issues (i.e. 'national identity', 'minority rights', 'linguistic human rights', 'the education of linguistic minorities', 'language shift,' 'sign languages' and 'linguistic imperialism'), the issues that will be dealt with here are more broadly defined. They include: 'the history of the field', 'language practices in different domains of society', 'ideas and beliefs about language', and 'the practical side of LPP'. Readers who are familiar with Spolsky's approaches to language policy (cf. Spolsky 2004 and 2012) and language management (Spolsky 2009) will have noticed that the last three issues loosely resemble the three components which, according to Spolsky, are part of language policy: i.e. language practices, language beliefs and language management. Spolsky (2009:4) considers these components to be "interrelated but independently describable" and that is also the way in which the issues as presented here (cf. 3.2, 3.3 and 3.4) should be understood. They are interrelated, yet can be independently described. And they represent a different sort of focus in current research on LPP.

\subsection{History of the field}

Most of the introductory works and articles on language policy and planning contain a section on the field's history. They sometimes make reference to the fact that Cebollero (1945) - according to Spolsky (2004:11) — is the first book in the Library of Congress to include 'language policy' in its title. They often refer to the fact that language planning as a term was coined by Haugen who, by his own account, launched the term in his article "Planning for a Standard Language in Modern Norway" (1959) after having heard Uriel Weinreich using it in a seminar at Columbia University in New York (Haugen 1987:626). ${ }^{2}$ They sometimes also briefly sketch the development of the discipline from the 1960s until present day before turning to a discussion of current trends or topical issues.

As far as the development of models and frameworks in LPP is concerned, Kaplan and Baldauf (1997) offer a very comprehensive overview that is illustrated with a multitude of case studies and which, according to Edwards (2012:430), still is "the single most comprehensive overview". In the last decade, Kaplan and Baldauf's standard work on LPP has been complemented with works that focus more on the identification of phases of research in language policy and planning while

2. For those interested in petty facts: Referring to his own work on languages in contact and the first edition of Kloss' book on Die Entwicklung neuer germanischer Kultursprachen von 1800 bis 1950 (Kloss 1952), Weinreich (1954[1968]:314) refers to standardization as "a process of more or less conscious, planned and centralized regulation of language" (emphasis is mine). 
simultaneously commenting on the thematic preoccupations of different scholars and their ideas and beliefs (some would refer to them as 'ideologies') about language in general and LPP in particular (cf. Ricento 2000, 2010; Wiley 2000, 2002; Tollefson 2002; Nekvapil 2011; Jernudd \& Nekvapil 2012; Johnson \& Ricento 2013).

When trying to roughly phase the field of LPP starting in the 1960s, one ends up with three broad phases. The first phase of systematic research on LPP started in the 1960s and ran until the late 1970s. Apart from developing the basic LPP terminology, LPP frameworks and focusing on the contribution of education to language problem solving in developing nations, research during this phase was concerned with technical aspects of LPP actions aiming at influencing the corpus and the status of (minority) languages (cf. Jernudd \& Nekvapil 2012:22-27 for an overview). When the second phase of LPP took off around the early 1980s, LPP concepts were further refined and LPP was increasingly linked to the study of societal language conflict that already embryonically featured in the early days of sociolinguistics, the sociology of language and research on language contact (cf. Darquennes 2010, 2013). Specific for the second phase was, however, above all the critical discussion of the rational approaches to LPP in the first phase, the limitations and the negative effects of LPP, as well as the ideological nature of LPP (cf. Tollefson 2002 and Ricento 2000, 2010). Towards the turn of the millennium, a third and still ongoing phase emerged. Characteristic of this phase is that - compared to earlier LPP research - more systematic attention is paid to "the variety of dayto-day practices and techniques (governmentality) that effectuate policies (stated or unstated) and the ideologies (often widely accepted as commonsense, and hence, non-ideological) which inform particular social outlooks on a range of issues involving language" (Ricento 2010:224). Johnson and Ricento (2013:13) refer to the current phase in LPP research as the "emergence of the ethnography of language policy" (cf. also 3.3 below).

As announced, the description of the phases as presented above is a very general one. It is based on some of the findings of a strand of research that is still developing and would profit from an expansion in at least two directions. On the one hand, efforts should be taken to enrich general overviews of the history of LPP since the 1960s with complementary information on LPP as it can be found, for example, in the (historical) overviews of LPP (research) in many corners of the world as they regularly appear in Current Issues in Language Planning (cf., e.g., Neustupny \& Nekvapil 2003 on Czech). On the other hand, the history of the field also needs to take into account the scholarly activity on language policy and language planning avant la lettre. Many scholars already do that by pointing to the work of 17th century language academies (cf., e.g., Wright 2004), to the LPP mechanisms that were at work during the long 19th century (cf., e.g., much of the contributions in Deumert and Vandenbussche 2003), to ideas on language planning in Russian linguistics and the works of the Prague School (cf., e.g., Garvin 1964 as well as Nelde 1990). One could, however, also dig a bit deeper into the contributions made by researchers active in so-called folklore research (Volkstumsforschung) in the early 20th century (cf. much of the work of the German Ausland-Institut which, as Hornberger and Pütz (2006:7) note, is indeed a sort of a "goldmine", be it one that is heavily affected by the ruling ideology in Germany at that time (cf. Hutton 1999 and Wiley 2002). Apart from that it would be advantageous if, in the near future, attention could be given to the LPP analyses provided in much of the works published in the field of historical sociolinguistics. Aware of the challenges that historical investigations pose for sociolinguistics in general and the study of LPP in particular (cf. Wiley 2006), many of these works (cf., e.g., Elspass et al. 2007 as well as Langer et al. 2012) could contribute to putting the outcomes of current research on ideas and beliefs about language and the actual language practices in different parts of society in a (comparative) historical perspective. 
3.2 Language practices in different 'domains' or 'spaces' of society

As far as language practices are concerned, LPP research initially tended to focus above all on the influence of top-down LPP on language practices in (semi-)official domains of language use in the nation-state. Nowadays, the focus is on 'top-down' as well as 'bottom-up', formal as well as more informal, overt as well as more covert LPP activities in virtually all possible domains of society or, to use a more contemporary concept: in all possible societal 'spaces' situated on a public-private continuum. Next to focusing on LPP at the level of state, regional and local governments and at the supranational level (e.g. the United Nations, the European Union, the Council of Europe, l'Agence Internationale de la Francophonie, ...), research addresses LPP in families (cf. Curdt-Christiansen 2013), deaf communities (cf. Wilcox et al. 2012), call centers (cf. King 2009a), universities (cf. Lindström 2012), health care settings (cf. Ramanathan 2010), army divisions (cf. Altermatt 2006), the media (cf. Wright 2013), the workplace (cf. Cadier and Mar-Molinero 2012), inter alia.

LLP research on language practices at the individual and/or the group level not only tries to answer the extended Fishman-question (cf. Fishman 1965) 'who uses which language (variety) with whom, when and why in the context of which kind of LPP activities (cf. the ones identified in Section 2)?' It also provides information on how certain actors (attempt to) influence other people's language practices by means of certain LPP activities that are based on certain ideas and beliefs about language. And an additional point of interest is whether those who (attempt to) influence the language behavior of others share these other people's ideas and beliefs about language. In its most comprehensive form, research focusing on language practices in a certain domain or space of language use in society thus links language practices to beliefs and ideas about language and to the language management strategies of those who (attempt to) influence the language behavior of others. It profits from as well as influences research on the issues described under 3.3 and 3.4.

\subsection{Ideas and beliefs about language}

Ideas and beliefs about language play a double role in LPP research. On the one hand, LPP research is concerned with the study of ideas and beliefs about language at the macro-level of society and/ or the micro-level of society (whether or not in relation to language practices and the way in which certain actors (try to) exert influence on these practices). LPP research dealing with ideas and beliefs about language focuses, for example, on ideas and beliefs concerning the (im)purity or the hybridity of languages and language varieties (cf. O'Rourke \& Ramallo 2011), the value of one language variety as opposed to another in a certain setting (e.g., a church, cf. Woods 2006), the desirability to use one language to the detriment of another because of political, social, or economic reasons (cf. many of the contributions in Castiglione \& Longman 2007). It profits considerably from the research on language ideologies that dates back to the $1960 \mathrm{~s},{ }^{3}$ yet started to boom in the 1990s (cf. Schieffelin, Woolard \& Kroskrity 1998). On the other hand, ideas and beliefs about language not only are an 'object of study' but also color LPP research itself. Like any other form of sociolinguistic research, LPP research is not neutral (cf. Gorter 2012:100; Edwards 2012:431) but subject to the researcher's and/or his research community's ideas and beliefs about language that, for example, shine through in the terminology used to approach LPP questions. That becomes obvious when looking at the way in which the research of scholars on LPP in developing nations has been and still is being criticized from a 'postcolonial' and 'postmodern' perspective for using a 'modern' rational approach to LPP that reflected a belief in progress which was typical of the post-WWII period (cf. Tollefson 2002;

3. Cf. Kloss' reference to ideologies in the preface of his book entitled Grundfragen der Ethnopolitik im 20. Jahrhundert (1969). 
Ricento 2010). It also shines through in the way in which LPP literature approaches questions of linguistic diversity in contemporary society.

When looking at LPP literature on linguistic diversity with the history of hyphenated linguistics in mind, a considerable part of it seems to reflect a sort of 'divide' that already marked the early days of sociolinguistics. On the one hand, there is literature that is rooted in the tradition of macro-sociolinguistics and the sociology of language and tends to focus on 'language problems' in pre-defined social groups (for example 'speech communities'; 'majorities'; indigenous, immigrant, affluent or other 'minorities', ...). The 'language problems' concern the corpus, the status, the acquisition and/or the prestige of a 'named language' used by the pre-defined social group(s) in a supranational, a national, regional and/or a local setting (cf. Truchot 2008; Darquennes 2010; Plasseraud 2012). On the other hand, there is literature that is rooted in the ethnography of speaking and takes a view on language as being dynamic, personal, free, creative, open, and constantly evolving as a starting point (cf. Shohamy 2006). This literature focuses on the intricate interplay of different 'repertoires', 'styles' and 'registers' that color much of everyday interpersonal communication in the often 'transnational' and 'hyperdiverse' urban 'communities of practice' or 'networks' as they emerge in contemporary society (cf. Blommaert \& Rampton 2011). It would go much too far to state that - in terms of ideas and beliefs about language - researchers interested in LPP questions would be either entirely rooted in a discourse that celebrates 'homogeneity' or in one that celebrates 'heterogeneity'. Nevertheless, the fact that different points of view (macro vs. micro), different methods and a different kind of vocabulary are used does not make it easy to combine these discourses. The search for possible synergies between discourses on 'heterogeneity' and discourses on 'homogeneity' poses a challenge to research on LPP especially when it comes to the formulation of recommendations on how to shape policies on linguistic diversity or a multilingual society. ${ }^{4} \mathrm{~A}$ related challenge concerns the reflection on the tools and the resources that are necessary to implement such policies.

\subsection{The practical side of LPP}

Some of the entries on LPP in the Encyclopedia of Applied Linguistics (Chapelle 2013) explicitly stress the need for a renewed interest in the more practical dimensions of LPP. Towards the end of his contribution on language problems as constructs of ideology, Ozolins (2013:3115), while commenting on the role of agencies in LPP actions, emphasizes that "ideological stances and intentions will yield little, and may remain emptily symbolic, if language-planning technologies cannot be effectively put in place and help to make new language practices viable, acceptable, and rewarding for those using that language or form”. And Schiffman (2013:3091) closes his contribution on language policy and multilingualism with the statement that more attention ought to be paid to scrutinizing "the implementation of language policies" and focusing more on "practical and empirical issues".

In recent years, research focusing on the practical side of LPP (and here especially the problems related to policy-formulation and policy-implementation) has certainly been underrepresented when compared to research focusing on ideologies. It has, however, not been totally neglected. As far as minority language studies are concerned, Fishman (1991), for example, managed to renew the attention for the more practical side of LPP already at the beginning of the 1990s with his volume

4. Backed-up by Johnson and Ricento (2013:14) it can be claimed that currently - and here, it seems, most of all on the side of those who engage in the ethnography of language policy - attempts are made to combine macro- and micro-perspectives and that precisely these attempts are considered to have the potential of pushing the field forward. 
entitled Reversing Language Shift: Theoretical and Empirical Foundations of Assistance to Threatened Languages. Even though Fishman's approach to language shift reversal can be criticized on a number of points (cf. Jernudd \& Nekvapil 2012:32 for an overview), it succeeded in giving a strong impetus to research on the development of tailor-made strategies aiming at the preservation of the world's linguistic diversity. The many works on language shift reversal that have appeared over the past years (cf. Williams 2000; Hinton \& Hale 2001; King 2001; etc.) have all helped to bring the relevance of Haugen's principles of the ecology of language (Haugen 1972) for LPP back to the fore.

Besides works on language shift reversal, also much of the LPP research in post-apartheid South Africa helped to renew the interest in the more practical side of LPP. Webb (2002), for example, devotes an entire chapter to 'language management' in the South African context and offers a framework for language management coupled with a description of language management structures and agencies. These days, the (historical) role of language management agencies in different kinds of settings meets with increasing attention (cf. Spolsky 2011; Edwards 2012). Researchers not only critically assess the outcomes of LPP activities that aim at modifying the corpus of a language (variety). They also pay attention to the evaluation of LPP activities (a topic put on the map by Rubin, cf. Rubin 1983) that pertain to the status and the acquisition of a language (variety). All of this shows that current research on LPP is partly characterized by a sort of 'pragmatic turn'. The basic idea behind this pragmatic turn is that researchers should not only reflect on what kind of LPP activities are or should be developed in a specific context and why certain activities may be said to be more justified than others, but rather how certain LPP goals can be reached and if some practical way of reaching them is preferable to other ways (which is, in broad terms, the philosophy behind much of Grin's work on LPP, cf. Grin et al. 2002; Grin 2003 as well as Kymlicka \& Grin 2003). The 'how' of LPP forces researchers to become more than observers and analysts and raises questions concerning the contribution of LPP research to actual LPP in society or, in other terms, the impact of LPP research on society.

\section{The impact of LPP research on society}

The question concerning the impact of LPP research on society is a very broad one. It cannot be answered in a straightforward way because of at least two reasons. One reason concerns the complexity of the field of LPP itself which leads to the question of what kind of LPP research one has in mind when reflecting on its impact. The other reason has to do with the complexity of 'society' and the impossibility of providing information on the influence of research on LPP in macro- as well as micro-settings in all of the approximately 200 states of the world over which the approximately 6500 languages are asymmetrically divided. It is, therefore, all but surprising that researchers - if at all - tend to approach the question of the impact of LPP research on society in rather broad terms. In the literature that was consulted for this contribution the question is dealt with as part of reflections on the tasks of LPP researchers as 'descriptivists' and/or 'prescriptivists' (cf. Kaplan \& Baldauf 1997:301-303; Edwards 2012), reflections on the social responsibility and the impact of (applied) linguists (cf. Clyne 2007) or in terms of the roles of researchers in policy development (cf. Gorter 2012 who makes a distinction between researchers as 'academic scholars', 'policy advisers' and 'activists'). The remainder of this contribution is inspired by the approaches of Clyne (2007) and Gorter (2012). This means that the different 'roles' of academics working at university departments and doing research on LPP will be taken here as a starting point for some general reflections on the impact of their research on society. The reflections partly rely on a number of interviews with distinguished LPP scholars that appeared in previous issues of Language Policy (cf. King 2009b; Shohamy 2009; Gorter 2011 and Yitzhaki 2012). They are, however, mainly nourished by own experiences with and observations of academic research on top-down language planning in indigenous European 
minority settings from the point of view of macrosociolinguistics, the sociology of language and contact linguistics.

As far as the roles of academics are concerned, the view taken here is that these roles (as they often feature in contracts or university regulations) in most cases can be brought down to 'teaching', 'doing research' and 'rendering services' within a specific research field in a specific scientific domain. The field of LPP is generally considered to be part of applied linguistics which, relying on Knapp and Antos (2010:xi), can be broadly described as "a specific, problem-oriented way of "doing linguistics" related to the real-life world". According to Knapp and Antos (2010: xii), the objectives of applied linguistics are not limited to identifying, defining, clarifying and understanding linguistic (or, in a broader sense: language) problems. They also include the contribution of applied linguistics to the solution of linguistic problems and the evaluation of such solutions. If one assumes that LPP research (as part of applied linguistics) shares these objectives, then the question is how academics respond to these objectives in their different roles and what implications this has for the impact of LPP research on society.

In their role as a researcher, academics active in the field of LPP above all try to advance knowledge (cf. Clyne 2007:03.3). Enjoying academic freedom, they can do this in various ways (cf. Section 3). Some prefer to reflect on the history and the state of the art of their field or tackle questions related to the practical side of LPP. Others analyze, explain and scrutinize LPP practices and/or ideas and beliefs on LPP. Again others reflect on how societal language problems could best be solved or engage in the evaluation of LPP activities (which they sometimes helped to develop themselves, cf. infra).

The knowledge that academics gather as researchers is usually disseminated in a variety of ways. One classical way of disseminating results is through the publication of scientific articles and books. Another way of classical knowledge dissemination is teaching. Since these two ways of dissemination primarily target an academic audience, their impact on society is usually more an indirect than a direct one. The impact of the opinions expressed in university teaching and scholarly publications on language policy-making and/or language policy-implementation depends on the use that is made of these opinions by the audience (i.e. the students attending university courses and the readers of scientific works on LPP). If, for example, certain students at some stage in their life become (language) policy advisers in government departments or other agencies, it is not unlikely that they will make use of certain ideas that were passed on to them in seminars and/or through scientific literature. That is the reason why Fishman, Ferguson and Das Gupta (1968: x) stressed the importance of the 'institutionalization' of research on societal language problems. As Clyne reports in an interview in Language Policy (cf. Gorter 2011:62), the presence of trained linguists in, for example, government departments has had a positive effect on the development of an Australian national language policy based on opinions as expressed in LPP literature in the 1970s and the 1980s. And in indigenous European language minority settings, language policy has also benefited greatly from the presence of trained sociolinguists in government departments who eagerly consult academic LPP literature and enrich it on the basis of their own expertise (cf. the work of Aldekoa \& Gardner 2002 as well as Zalbide et al. 2006 on the Basque Autonomous Community).

Of course, teaching courses and producing papers or books is not the only way in which academics disseminate research results. Urged on to render social and scientific services, many academics active in the field of LPP provide expert knowledge to various sorts of stakeholders (local or regional governments, schools, companies, ...), give public lectures or intervene in public debates. In doing so, they provide what Clyne (2007:03.1) refers to as "leadership in understanding how [language] works and responsible insights into the uses and abuses of language in society". In Europe this kind of leadership can be witnessed on the European Day of Languages that is organized every 
year in September since 2001. On that occasion, linguists tend to shed light on some of the societal language problems surrounding Europeans in contributions to newspapers. In many parts of the world intellectual leadership is also provided on television or in newspapers when governments decide to once again change foreign language provisions in schools and/or hesitate to invest in forms of bi- or multilingual education. The impact of academics' contributions to public debates on LPP in practice is hard to measure. One can assume, however, that the influence is rather an indirect one. By affirming, contradicting or adjusting ruling ideas and beliefs about language in (parts of) society, these kinds of interventions above all aim at influencing the ruling mindsets on language questions.

A less visible way in which academics - either indirectly or more directly - contribute to language policy-development and, at times, even language policy implementation is when they act as LPP advisers, for example as a member of an expert group that gives advice at the local, regional, national and/or supranational level. The question of whether the contribution of an academic (in his role as adviser) to the development or the revision of a language policy is a more direct or rather an indirect one depends on numerous factors. It depends on the willingness of the academic and the people the academic is working with (politicians, language policy bureaucrats, etc.) to reach a consensus on certain questions. It depends on the academics' acceptance of viewing language policy questions as part of a broader social policy. It also depends on the academics' ability and willingness to adapt his scholarly views on LPP to non-scholarly views (including political views) on LPP, to take (hidden) political agendas into account, etc. Things become even more complicated (and/ or frustrating) at the stage of decision-making on questions related to policy-implementation since political decisions then interfere with discussions on financial and other practical issues. Reflecting on the role of scholars who act as experts or some kind of language 'managers', Edwards (2012:435) states the following:

"Language 'managers' should not delude themselves into thinking that they are prime movers. If not from the beginning, then certainly at the point at which any application becomes socially important, planning is subservient to the demands of non-academic interests, with social and political agendas whose remit is typically broader than language alone. As in other areas of public life, 'experts' are called upon as needed, and their recommendations are either implemented or gather dust according to how well they support or justify desired positions."

One could be tempted to accuse Edwards of being too pessimistic. When reading the Language Policy-interview with Theodorus Du Plessis, a seasoned specialist on LPP in the South African context who has ample experience with the more practical-side of LPP ranging from policy-making to policy-implementation, one gets the impression, however, that there might indeed be quite some truth in these observations (cf. Yitzhaki 2012). Whether these kinds of observations should encourage academics to refrain from acting as experts and policy advisers is, however, a different matter. That is certainly not the message Edwards (2012) wants to spread. He above all wants to point out that in terms of the involvement of academics in policy-making and policy-implementation it is not their linguistic expertise that is most essential, but their ability to adapt to non-academic approaches to LPP and to persevere without losing their patience and their critical stance.

Apart from acting as an expert or a policy adviser, academics - while perhaps stretching the limits of their role as 'service providers' - can also opt for a role as an activist. In this role, academics more or less give up their 'detached' stance when trying to exert a more direct influence on language policy-making and language policy-implementation. Here too, it is not certain whether they will be able to exert a direct influence since also in their role as activists they have to take the opinions and the manoeuvres of other actors (politicians, bureaucrats, enthusiasts, ...) into account. 
To what extent academics engage in the different roles listed above is highly dependent on their own interpretation of their profession and the challenges and opportunities they are confronted with in the course of their careers. As to the impact of their research on society, many might hold the philosophy that one can lead a horse to the water but that one cannot make it drink. Others might be convinced that one can or should at least try to.

\section{Outlook: Towards a history and sociology of applied linguistics}

It cannot be stressed enough that the reflections on the impact of LPP research on society as presented in the previous section are very general ones. The issues that have been addressed in a rather loose and preliminary way in this contribution require a more thorough discussion. For example, it would be interesting to supplement them with existing views on the roles of the researcher as they exist in much of the literature that deals with ethical issues in language documentation or with linguistic human rights. Especially for an association like AILA, that started off in 1964 with support of the Council of Europe, it could be a challenging endeavor to promote research that focuses on the contribution of applied linguistics to the development of a European language policy at the level of the Council of Europe from the 1960s until the present day. It would allow applied linguists to gain insights into the functioning and the impact of expert groups. Questions that could be tackled include the following: how were these groups (as they existed and still exist, for example, on regional and minority languages and language education) composed, how were different (research) ideas brought in and by whom, how were these ideas discussed, received and put on the agenda by bureaucrats and politicians, how were they translated into policy documents and relegated to the member states? Now that many of the actors that were active in the realm of the Council of Europe are still around, firsthand information can still be gathered with relative ease. Investing in such a historical as well as a sociological account of applied linguistics would help the research community to gain a more complete understanding of the history of the field, of the way in which research knowledge makes it to the policy level and of the way in which personal ties and coincidences sometimes have an influence on language policy-making. It would provide the applied linguistics community with a better insight into the relevance of its trade.

\section{References}

Aldekoa, J. \& Gardner, N. 2002. Turning knowledge of Basque into use: Normalisation plans for schools. International Journal of Bilingual Education and Bilingualism 5(6): 339-354. DOI: $10.1080 / 13670050208667766$

Altermatt, B. 2006. L'armée et les langues: Une partie de la culture suisse. La diversité des langues au sein de l'armée suisse. Civitas. Revue de Société et Politique 9(10): 20-23.

Baldauf, Richard B. 2004. Language policy and planning: Recent trends, future directions. Paper presented at the American Association of Applied Linguistics, Portland, OR, May 2004. Retrieved September 2013. $<$ http://espace.library.uq.edu.au/view/UQ:24518>

Blommaert, J. \& Rampton, B. 2011. Language and superdiversity. Diversities 13(2). Retrieved September 2013. <http://www.unesco.org/shs/diversities/vol13/issue2/art1>

Cadier, L. \& Mar-Molinero, C. 2012. Language policies and super-diversity in contemporary urban societies: The case of the city of Southampton. Current Issues in Language Planning 13(3): 149-165. DOI: $10.1080 / 14664208.2012 .722376$

Castiglione, D. \& Longman, C. (eds). 2007. The Language Question in Europe and Diverse Societies. Political, Legal and Social Perspectives. Oxford: Hart Publishing.

Cebollero, P.A. 1945. A School Language Policy for Puerto Rico. San Juan de Puerto Rico: Imp. Baldrich. Chapelle, C.A. (ed.). 2013. The Encyclopedia of Applied Linguistics. Oxford: Wiley-Blackwell. 
Clyne, M. 2007. Are we making a difference? On the social responsibility and impact of the linguist/applied linguist in Australia. Australian Review of Applied Linguistics 30(1): 03.1-03.14. DOI: 10.2104/aral0703 Cooper, R.L. 1989. Language Planning and Social Change. Cambridge: CUP.

Curdt-Christiansen, X.L. 2013. Family language policy: Socio-political reality versus linguistic continuity. Language Policy 12: 1-6. DOI: 10.1007/s10993-012-9269-0

Darquennes, J. 2010. Language contact and language conflict in autochthonous language minority settings in the EU: A preliminary round-up of guiding principles and research desiderata. Multilingua 29(3-4): 337-351. DOI: 10.1515/mult.2010.016

Darquennes, J. 2013. Language policy and planning in indigenous language minority settings in the EU. Revue Française de Linguistique Appliquée XVIII(2): 103-119.

Deumert, A. \& Vandenbussche, W. (eds). 2003. Germanic Standardizations. Past to Present. Amsterdam: John Benjamins. DOI: 10.1075/impact.18

Edwards, J. 2012. Language management agencies. In The Cambridge Handbook of Language Policy, B. Spolsky (ed.), 418-436. Cambridge: CUP. DOI: 10.1017/CBO9780511979026.026

Elspass, S., Langer, N., Scharloth, J. \& Vandenbussche, W. (eds). 2007. Germanic Language Histories from Below (1700-2000). Berlin: De Gruyter. DOI: 10.1515/9783110925463

Fishman, J.A. 1965. Who speaks what language to whom and when? La Linguistique 1(2): 67-88.

Fishman, J.A. 1972. Language and Nationalism. Two Integrative Essays. Rowley MA: Newbury House.

Fishman, J.A. 1991. Reversing Language Shift. Theoretical and Empirical Foundations of Assistance to Threatened Languages. Clevedon: Multilingual Matters.

Fishman, J.A., Ferguson, C. \& Das Gupta, J. 1968. Preface. In Language Problems of Developing Nations, J.A. Fishman, C. Ferguson \& J. Das Gupta (eds), ix-xi. New York NY: John Wiley \& Sons.

Garvin, P. (ed.). 1964. A Prague School Reader on Esthetics, Literary Structure, and Style. Washington DC: Georgetown University Press.

Gorter, D. 2011. Questions for ... Michael Clyne. Language Policy 10: 59-68. DOI: 10.1007/s10993-0109189-9

Gorter, D. 2012. Minority language researchers and their role in policy development. Language, Culture and Curriculum 25(1): 89-102. DOI: 10.1080/07908318.2011.653060

Grin, F. 2003. Language Policy Evaluation and the European Charter for Regional or Minority Languages. New York NY: Palgrave Macmillan. DOI: 10.1057/9780230502666

Grin, F., Moring, T., Durk, G., Häggman, J., ÓRiagáin, D. \& Strubell, M. 2002. SMiLE - Support for Minority Languages in Europe. Brussels: European Commission.

Haarmann, H. 1990. Language planning in the light of a general theory of language: A methodological framework. International Journal of the Sociology of Language 86: 103-126. DOI: 10.1515/ijsl.1990.86.103

Haugen, E. 1953. The Norwegian Language in America: A Study in Bilingual Behavior. Philadelphia PA: University of Pennsylvania Press.

Haugen, E. 1959. Planning for a standard language in modern Norway. Anthropological Linguistics 1(3): 8-21. Haugen, E. 1972. The ecology of language. In The Ecology of Language, A.S. Dil (ed.), 325-339. Stanford CA: Stanford University Press.

Haugen, E. 1987. Language planning. In Sociolinguistics, Vol. 1, U. Ammon, N. Dittmar, K.J. Mattheier \& P. Trudgill (eds), 626-637. Berlin: De Gruyter.

Hinton, L. \& Hale, K. 2001. The Green Book of Language Revitalization in Practice. San Diego CA: Academic Press.

Hornberger, N. 2006. Frameworks and models in language policy and planning. In An Introduction to Language Policy. Theory and Method, T. Ricento (ed.), 24-41. Oxford: Blackwell.

Hornberger, N.H. \& Pütz, M. 2006. An interview with Joshua A. Fishman. In Language Loyalty, Language Planning and Language Revitalization. Recent Writings and Reflections from Joshua A. Fishman, N.H. Hornberger \& M. Pütz (eds), 1-25. Clevedon: Multilingual Matters.

Hutton, C. 1999. Linguistics and the Third Reich. Mother-tongue Fascim, Race and the Science of Language. London: Routledge. 
Jernudd, B. \& Nekvapil, J. 2012. History of the field: A sketch. In The Cambridge Handbook of Language Policy, B. Spolsky (ed.), 16-36. Cambridge: CUP. DOI: 10.1017/CBO9780511979026.004

Johnson, D.C. \& Ricento, T. 2013. Conceptual and theoretical perspectives in language planning and policy: Situating the ethnography of language policy. International Journal of the Sociology of Language 219: $7-21$.

Kaplan, R.B. \& Baldauf, R.B. 1997. Language Planning. From Practice to Theory. Clevedon: Mutilingual Matters.

King, K.A. 2001. Language Revitalization Processes and Prospects. Quichua in the Ecuadorian Andes. Clevedon: Multilingual Matters.

King, K.A. 2009a. Global connections: Language policies and international call centers. Language Policy 8: 1-3. DOI: 10.1007/s10993-008-9123-6

King, K.A. 2009b. Questions for Joan Rubin. Language Policy 8: 403-409. DOI: 10.1007/s10993-009-9129-8 Kloss, H. 1952. Die Entwicklung neuer germanischer Kultursprachen von 1800 bis 1950. Pohl: München.

Kloss, H. 1969. Research Possibilities on Group Bilingualism. Québec: Université Laval, Centre International de Recherches sur le Bilinguisme.

Knapp, K. \& Antos, G. 2010. Introduction to the handbook series. Linguistics for problem solving. In Handbook of Language and Communication: Diversity and Change, M. Hellinger \& A. Pauwels (eds), v-xv. Berlin: De Gruyter.

Kymlicka, W. \& Grin, F. 2003. Assessing the politics of diversity in transition countries. In Nation-Building, Ethnicity and Language Politics in Transition Countries, F. Daftary \& F. Grin (eds), 1-27. Budapest: Open Society Institute.

Langer, N., Davies, S. \& Vandenbussche, W. (eds). 2012. Language and History, Linguistics and Historiography. Interdisiplinary Approaches. Frankfurt: Peter Lang.

Lindström, J. 2012. Different languages, one mission? Outcomes of language policies in a multilingual university context. International Journal of the Sociology of Language 216: 33-54.

Lo Bianco, J. 2013. Language policy and planning: Overview. In The Encyclopedia of Applied Linguistics, C.A. Chapelle (ed.), 3094-3101. Oxford: Wiley-Blackwell.

Nekvapil, J. 2011. The history and theory of language planning. In Handbook of Research in Second Language Teaching and Learning, Vol. II, E. Hinkel (ed.), 871-887. London: Routledge.

Nelde, P.H. 1990. Language planning and the Prague School. Buffalo Working Papers in Linguistics 90(1): 142-147.

Neustupny, J.V. \& Nekvapil, J. 2003. Language management in the Czech Republic. Current Issues in Language Planning 4(3-4): 181-366. DOI: 10.1080/14664200308668057

O’Rourke, B. \& Ramallo, F. 2011. The native-non-native dichotomy in minority language contexts: Comparisons between Irish and Galician. Language Problems \& Language Planning 35(2): 139-159. DOI: $10.1075 /$ lplp.35.2.03oro

Ozolins, U. 2013. Language problems as constructs of ideology. In The Encyclopedia of Applied Linguistics, C.A. Chapelle (ed.), 3107-3116. Oxford: Wiley-Blackwell.

Plasseraud, Y. 2012. L'Europe et ses minorités. Grenoble: Presses universitaires de Grenoble.

Ramanathan, V. 2010. Introduction to thematic issue: Language policies and health. Language Policy 9: 1-7. DOI: $10.1007 / \mathrm{s} 10993-009-9154-7$

Ricento, T. 2000. Perspectives in language policy and planning. In Ideology, Politics and Language Policies, T. Ricento (ed.), 9-24. Amsterdam: John Benjamins. DOI: 10.1075/impact.6

Ricento, T. 2006. An Introduction to Language Policy. Theory and Method. Oxford: Blackwell.

Ricento, T. 2010. Models and approaches in language policy and planning. In Handbook of Language and Communication: Diversity and Change, M. Hellinger \& A. Pauwels (eds), 211-240. Berlin: De Gruyter.

Rubin, J. 1983. Evaluating status planning: What has the past decade accomplished? In Progress in Language Planning, J.A. Fishman (ed.), 329-343. Berlin: Mouton.

Schieffelin, D., Woolard, K. \& Kroskrity, P.V. (eds). 1998. Language, Ideologies, Practice and Theory. New York NY: New York University Press. 
Schiffman, H. 2013. Language policy and multilingualism. In The Encyclopedia of Applied Linguistics, C.A. Chapelle (ed.), 3084-3092. Oxford: Wiley-Blackwell.

Shohamy, E. 2006. Language Policy. Hidden Agendas and New Approaches. London: Routledge.

Shohamy, E. 2009. Questions for Robert Cooper. Language Policy 8: 89-94. DOI: 10.1007/s10993-008-9114-7 Spolsky, B. 2004. Language Policy. Cambridge: CUP.

Spolsky, B. 2009. Language Management. Cambridge: CUP. DOI: 10.1017/CBO9780511626470

Spolsky, B. 2011. Language academies and other language management agencies. Language Policy 10: 285287. DOI: $10.1007 / \mathrm{s} 10993-011-9218-3$

Spolsky, B. 2012. What is language policy? In The Cambridge Handbook of Language Policy, B. Spolsky (ed.), 3-15. Cambridge: CUP. DOI: 10.1017/CBO9780511979026.003

Studer, P., Kreislmaier, F. \& Flubacher, M-C. 2008. Language Policy-planning in a European Context [Arbeitspapier 43]. Bern: Institut für Sprachwissenschaft.

Tollefson,J.W. 2002. Limitations of language policy and planning. In The Oxford Handbook of Applied Linguistics, Robert B. Kaplan (ed.), 416-425. Oxford: Oxford University Press.

Truchot, C. 2008. Europe: l'enjeu linguistique. Paris: La documentation française.

Webb, V. 2002. Language in South Africa. The Role of Language in National Transformation, Reconstruction and Development. Amsterdam: John Benjamins. DOI: 10.1075/impact.14

Weinreich, U. 1954[1968]. Is a structural dialectology possible? In Readings in the Sociology of Language, J.A. Fishman (ed.), 305-319. The Hague: Mouton.

Wilcox, S.E., Krausneker, V. \& Armstrong, D.F. 2012. Language policies and the deaf community. In The Cambridge Handbook of Language Policy, B. Spolsky (ed.), 374-395. Cambridge: CUP. DOI: 10.1017/ CBO9780511979026.023

Wildgen, W. 2005. Sprachkontaktforschung. In Sociolinguistics, Vol. 2, U. Ammon, N. Dittmar, K.J. Mattheier \& P. Trudgill (eds), 1332-1345. Berlin: De Gruyter.

Wiley, T.G. 2000. Continuity and change in the function of language ideologies in the United States. In Ideology, Politics and Language Policies, T. Ricento (ed.), 67-85. Amsterdam: John Benjamins.

Wiley, T.G. 2002. Heinz Kloss revisited: National Socialist ideologue or champion of language minorityrights? International Journal of the Sociology of Language 154: 83-97.

Wiley, T.G. 2006. The lessons of historical investigation: Implications for the study of language policy and planning. In An Introduction to Language Policy. Theory and Method, T. Ricento (ed.), 135-152. Oxford: Blackwell.

Williams, C.H. (ed.). 2000. Language Revitalization. Policy and Planning in Wales. Cardiff: University of Wales Press.

Woods, A. 2006. The role of language in some ethnic churches in Melbourne. In Explorations in the Sociology of Language and Religion, T. Omoniyi \& J.A. Fishman (eds), 197-212. Berlin: De Gruyter.

Wright, S. 2004. Language Policy and Language Planning. From Nationalism to Globalisation. Houndmills: Palgrave Macmillan.

Wright, S. et al. (ed.) 2013. New Media Practices - The Language Dimension [Sociolinguistica 27]. Berlin: De Gruyter.

Yitzhaki, D. 2012. Questions for Theodorus du Plessis. Language Policy 11: 273-281. DOI: 10.1007/s10993012-9244-9

Zalbide, M., Gardner, N., Erize, X. \& Azurmendi, M.-J. 2006. The future of Basque in RLS perspective. In The Case of Basque: Past, Present and Future, M.-J. Azurmendi \& I. Martinez de Luna (eds), 117-139. Andoain: Soziolinguistika klusterra.

\section{Author's address}

Université de Namur

jeroen.darquennes@unamur.be 